\title{
Heterogeneous Islam as a Cultural Identity of Multicultural Communities in the Suburbs of Pontianak
}

\author{
Yusriadi \\ Pontianak State Institute of Islamic Studies \\ Email: yusriadi.ebong@gmail.com \\ Imron Muttaqin \\ Pontianak State Institute of Islamic Studies \\ Email: imron.muttaqin@gmail.com
}

\begin{abstract}
This article discusses the variant of Islam that lives in a multicultural society in the Sungai Ambawang area in the suburbs of Pontianak City, West Kalimantan. In the Javanese, Bugis, Malay and Madurese communities, Islam has served as an important element in the formation of their cultural identity, thus causing them to be synonymous with the Islamic community. Islamic elements that are used and have become part of the culture of society include the choice of Islamic dates such as the Hijri month in determining the time of cultural activities, the use of Al-fitihah and several other verses from the Quran as well as shalawat and prayer, the use of mosques as a center of cultural activities and the involvement of Islamic religious leaders in traditional ceremonies. The use of these elements has become a hallmark of the community culture and its form has been preserved until today.
\end{abstract}

Keywords: Nusantara Islam, Culture, Identity, Multiculture, Sungai Ambawang

\section{INTRODUCTION}

The reaction of the Nahdliyin to Mama Dedeh who said "Nusantara Islam" has to be crossed out because the term does not exist in Islam, indicates a problem in understanding Islam in the Muslim community in Indonesia (NU Online, 2018: 1). At least, the preachers still need to figure out how to explain Islam to various groups. From an academic point of view this shows the scholars need to find out the ways to overcoming the problem of failing to understand socioanthropological facts. Scientists have shown that the interaction between Islam and local communities in a particular space presents the face of Islam in a different society. Abudin Nata, Ed. (2010) has shown that Islam must undergo a process of touch with the social environment ${ }^{1}$, which then presents

\footnotetext{
${ }^{1}$ See Barth (2001) to see how the environment affects a community. One community
} 
a different form of Islam from one place to another.

Azyumardi Azra (2015) argued that Islam in Indonesia has a distinctive form of display which he called 'flowery Islam'. The forms of behavior and religious affinity have led the community to have its own characteristics. In Indonesia, we know of groups such as Nahdlatul Ulama, Muhammadiyah, Jamaah Tabligh. On the other hand, the academic world has the terms of traditional and modern Islam, or cultural Islam, syncretic Islam, and Nusantara Islam, which has been used for more than 10 decades. This paper presents an overview of Islam that comes with local nuances in the community. This paper seeks to see the culture of the Islamic community that lives among multicultural communities. The data were taken from a multicultural community in Sungai Ambawang, the suburb of Pontianak, and from some additional literature on the community in his area.

\section{ISLAM AND WEST KALIMANTAN CULTURE}

Studies on Islam and culture in the community in West Kalimantan were conducted by Yusriadi and Hermansyah (2003). This study described the form of Malay people's belief in supernatural power. Islam practiced by the society is referred to as syncretic Islam and part of Islamization. Based on these studies, the term Islamization of science emerged which describes the compromise of two belief systems as a way for the spread of Islam. Similar descriptions are also presented in Hermansyah (2004, 2007, and 2010). Faisal Amin (2014) reinforced this conclusion. He used the term 'hybrid' to indicate the existence of one form of Islam that grew out of a mixture of native and local Islam in the community in Kapuas Hulu. This study found local elements which were mixed in people's beliefs when they worshiped. Yusriadi (2014a) also observed Islamic identity in the Malay community in the upper reaches of the Sambas River. This research stated that Islamic identity is used by the people to confirm their identity as Malay. Islam has significantly affected their culture, such as art and marriage. Islam is part of the cultural identity of society.

There are also other studies conducted in Kartiasa, Sambas, and Temuyuk, Kapuas Hulu (Zainuddin Isman, 2003). Similarities and differences in Malay culture in these two places are influenced by Islamic elements. Islam is the core of Malay culture here. While the difference lies in the paradigm of society in looking at something good or bad for them; the view that a good and valuable culture underlies the choice to maintain a certain cultural form in society (Muttaqien, 2016) In addition, there is a study by Prasojo (2011) regarding

that spreads in different spaces will gradually show a different identity. 
Islam that grows and gives nuances to the Dayak Kebahan people in Melawi. Islam is a differentiator in these rural communities. The presence of religion, in this case Islam, in people's lives certainly has created its own pattern.

A well-known study by Clifford Geertz $(1968 ; 1997)$ among others, describes how the social level of Javanese society influences the form of Islam. Social factors, especially occupations greatly influence the form of religious practice in society. For example, farmers tend to be grouped in the Abangan Islamic group, while employees belong to Priyai Islam. These factors --work and social class-- were also discussed in Robertson at.al (1997). Robertson elaborated the political issues that influenced the form of religious community. Although religion and politics are two different things, in practice, religion is often part of political life, and it affects other life's aspects. Political policies taken, especially relating to the field of religious life, will form or bring certain effects on the development of a religion and the behavior of its adherents.

Abudin Nata at.al (2010) mentioned a form of cultural Islam in society, to describe the form of acceptance of the religion. Although it is recognized that it is not easy to distinguish such religious typologies, because they are layered with other typologies, the characteristics of this adherent of cultural Islam are to translate religious practices in a local form. Azyumardi Azra (2015) used the term "flowery Islam" to describe the dynamics of religious practice in society. The practice of religion in one community when compared with another community often shows "differences" or distinctions, ranging from 'ritual' of tahlilan, nyekar or tomb pilgrimage, walimatus-safar (walimatul haj/ umrah), walimatul khitan, tasyakuran, to four monthly or seven monthly pregnancies, etc. All of these forms enrich the face of Islam. From an identity perspective, the forms of religious rituals displayed by the Muslim community above can be used as a differentiating aspect between one community and another. The identity used as a form of group markers is constructed from various aspects. There are aspects of language, art, food, tradition, ethnicity and religious knowledge (Shamsul A. Baharuddin, 2001, Abdur Rahman, 1999). These characteristics are maintained and developed so as to represent as the current form, in order to remain relevant as a characteristic of a cultural community. There is training, education, promotion or advertising, carried out by a group of people for the purpose of maintaining and strengthening that identity (Shamsul A. Baharuddin, 2001).

\section{MULTICULTURAL RESIDENTS IN AMBAWANG}

Sungai Ambawang is one of the residential areas located on the suburb of Pontianak City. It is located the east, in the Kubu Raya District. The population 
in Sungai Ambawang consists of Javanese, Malay, Bugis, Madura, Ahe or Kanayatn, and people of Chinese descent. In terms of religion, most Javanese, Malays, Bugis, Madurese, and a small number of Kanayatn and Chinese, are Muslim. Meanwhile, Kanayatn and Chinese, as well as a few Javanese, are mostly Catholic, Protestant, Hindu and Buddhist. Javanese are a fairly dominant group in the Sungai Ambawang region. In fact there is a village called Jawa tengah (Central Java). Regarding the Jawa tengah village in Sungai Ambawang, it was mentioned in Lontaan (1975: 23) who visited this village in the 1960s. The Javanese lived in the Sungai Ambawang area because they were given land from the Sultan of Pontianak in the 1950s (Turiman as quoted by Yusriadi, 2014; 2014b). However, some reported that they lived in Sungai Ambawang and formed their own villages through asettlement process, such as transmigration.

In addition to the Javanese, there are Madurese people. They have lived in the Sungai Ambawang area for a long time. Lontaan (1975) said the Madurese have been around since the 1960s. In the 1990s people affected by the riots in Sanggau Ledo and Sambas chose to live in this region. One of the ex-refugee villages of the Sambas Riot is Durian Village which is located not far from Jawa Tengah Village (Yusriadi at.al, 2009). The Malays are also found in the area around Sungai Ambawang (Lontaan, 1975). However, identification for them is often disguised by Bugis or Javanese identity. Bugis and Javanese who do not strictly implement traditional customs, are often referred to or refer to themselves as Malays. It is also the case with the Banjar people. Intermarriages between Muslim communities who later in the family environment uses the Malay language in communication, has identity implications. They also became Malays ${ }^{2}$.

The Bugis, although in the context of their culture are often synonymous with Malays, however, can still be identified by their own ethnicity. Lontaan (1975) described the existence of the Bugis community there. Veth (2012) also implicitly mentioned the existence of Bugis people who cultivate coconut in the North-Eastern region of Pontianak City. Some Bugis people who live here are relocated from various regions: Sungai Kakap, Teluk Pakedai, and Pontianak. The Bugis are concentrated on the banks of the Ambawang River or in small trenches as tributaries of Ambawang, as can be seen in the Parit Aim or Parit Seribut areas. The Bugis people settled along the small trenches

${ }^{2}$ There are two examples for this situation. The Secretary of the Malay Youth in Ambawang, Solihin, for example, actually has Bugis parents. While the Chairman of the Malay Youth, Edi Hasbi, has Javanese parents. The dual ethnic identity of the Malay in Sungai Ambawang has made ethnic identification a little complex and needs a long explanation. However, for the sake of this research, self-identification (claiming to be a certain ethnic group) is used. 
of the Ambawang River. Since they are concentrated and living not too far from the original area -it takes no more than a day of river travel-- it is easy for them to maintain or hold traditional and cultural activities.

The existence of the Ahe or Dayak people as a common name in Sungai Ambawang is also mentioned in Veth (2012: 572). Quoting Van Lijnden N.T., Veth mentioned the move of Dayaks from Mempawah to the Sungai Ambawang area. So is the Chinese. They are spread around Kuala Ambawang, the area around the Ambawang Bridge. On the other hand, in the newly built housing in 2010, there were quite a lot of Chinese people, for example, those living in Permata Trans Kalimantan housing complex. Outside the area, for example around the Ali Anyang Monument to Kampung Jawa Tengah, the Chinese were hardly found. This situation is indeed due to the fact that Chinese people are relatively new to this area ${ }^{3}$.

Practicing tradition in the community in the Sungai Ambawang region is quite strict. Every day or in a series of life cycles, the activity is carried out. This cultural activity is part of the identity of the groups. Ethnic rivalry in sociopolitical relations at the district and provincial levels of West Kalimantan, has to an extent affected this situation. Each competes to maintain its identity. In addition, the concentration of residential areas based on ethnicity also causes cultural activities to take place continuously.

\section{CULTURE OF THE PEOPLE IN AMBAWANG}

There is a tradition of "naik ayon" in the Malay-Bugis community in Ambawang when welcoming the birth of a child. The naik ayon is held on the 14th, 21st or 40th day of birth. But most of the Ambawang people chose the 40th day, on the grounds that they could save some money and the mother is quite well to take part in the ritual. The ritual for the mother is called baso lantai or also called cuci darah. This 40th day is the last massage for the mother, as well as the puerperal bath. This process is carried out by a shaman. This 40-day determination is in line with the concept of Nifas in Islam (Rasyid, 2001). In this event, the shaman plays an important role. The shaman leads the procession of the activity, by sprinkling fresh flour water on the chicken while reading the Shalawat. Then the chicken feet are rubbed against the floor where the mother gives birth on. If she did not give birth at home then the process of rubbing chicken feet can be done anywhere, but still in the mother's and baby's bedroom. After the procession was finished, it is followed by a congratulatory prayer read by one of the religious leaders.

${ }^{3}$ In Enthoven (1905) there is absolutely no mention of Chinese in the Ambawang area. The Chinese at that time lived around Pontianak, Sungai Kakap and Kubu. 
This procession can only be held with one person or can also be witnessed by many people depending on food preparation from the host. After a new congratulatory prayer, there is a sermon which is usually attended by many people. When it is read aloud, parents can cut their child's hair with scissors, if desired. People who cut their hair are selected from the elder (religious leaders, community leaders or the child's close relatives) who are present in the event. In the month of Safar, the 7th month of the Islamic calendar, there is a buang-buang ritual. Buang-buang is a cultural activity related to throwing things into the river. The real intention is to make offerings in the river for supernatural beings who lives in the vicinity in order to get permission for the activities to be carried out ${ }^{4}$.

The properties needed for the procession are: bereteh, yellow rice, beeswax, raw chicken eggs, Bugis oil (bauk oil), betel leaves, areca nut, betel lime, and gambier. In this buang-buang activity, chicken eggs are also used. The eggs are splashed with a small amount of oil. After that, they are discarded simultaneously while saying: Bismillahirrahmanirrahim, Assalamualaikum Nabi Haidir (then the names of the descendants who perform the ritual). After buang-buang, the white plate where the items are to be wasted were placed is filled with water and rubbed onto the face of the person who holds the event. In the ritual of naik ayon then the face of the father, mother and baby are rubbed. In a bridal event, the face of the bride is rubbed, and in a circumcision event, the person to be circumcised is rubbed. This ritual is performed by a village shaman and a traditional midwife.

Maulid is one of the important activities in the community here. In the month of Maulid, the people of various ethnicities welcom the birthday of Prophet Muhammad with various events. Also in the month of Maulid, the birthday of Prophet Muhammad is celebrated on a large scale in the Madurese community, in their homes and mosques. Cooking and eating together are packed with reading and prayer. The preparations have been made several days before the birthday of the Prophet. In addition, the Madurese also make a special speech during the Hajj month. Like the events of other months, this activity is carried out at home and also in the mosque or musalla.

The same can be seen in the month of Ramadan. In this month, Muslims are required to fast. In the Javanese community there is a Medunan event, which is a salvation program in their homes to welcome the coming of the holy month of Ramadan. In this activity they invite neighbors, for one month, alternately. When fasting takes place the atmosphere in the community, day and night

${ }^{4}$ The Buang-buang procession is still carried out by the Ambawang community, among others, in the events of wedding, naik ayon, and circumcision. 
looks lively. Pasar Juadah appears along the way presenting various cakes or snacks to break the fast. Some snacks are traditional foods that occasionally appear. Breaking fast together is carried out between families, arisan groups, colleagues, and even communities. In particular, before breaking the fast and Eid, bamboo cannons and carbide cannons are sounded, making the space boom.

Ramadan is an important month in the Madurese culture. The Madurese hold selekoran on the 21st night of Ramadan. Before evening, residents prepare food and distribute it to their relatives and closest neighbors. Generally the food they cook is rice and side dishes, such as chicken and eggs. Women also prepare food to be taken to the mosque for the night because in the evening after the tarawih prayer, people gather to read prayers and eat together. All food brought here will be put in the middle and prayer will be read first. Two days after this, a special event called skemian will be held. On the evening of this day, they prepare sticky rice and eat together at the mosque. They also deliver the food to the nearest neighbors. Usually when delivering sticky rice to a neighbor's house, the plates they use will be replaced with new ones or filled with sticky rice. They return each other's favor. After that, in the Eid-ul-Fitr festivities, the Madurese people welcome it with joy. Like other communities, Lebaran (telesan) is celebrated several days. The first Eid is called telesan kupa', when each family prepares ketupat and other types of food for the relatives who come to visit. After that the next Eid day is filled with visits between neighbors, relarives and colleagues. Muslims of various ethnic groups also give color to the Hajj month. Especially in the Madurese community, the Eid of Hajj is filled with a ter-ater tradition. In Bugis and Malay society, cakes and snacks are served.

Circumcision is the cutting off of the foreskin of a young boy/man's genital which is an Islamic tradition following what Abraham did. Circumcision with traditional processions is performed on boys. Circumcision on boys is generally filled with thanksgiving events, both before and after the event. Before the circumcision is carried out, both parents must prepare a traditional ceremony which aims to make the child in the circumcision process easier and not disturbed by 'evil spirits'. The item that must be prepared is yellow cloth in the form of a sarong. People believe that if they do not use yellow cloth, they may have difficulties and long periods of healing. Before the event is held, there is a buang-buang procession with the aim that the boy being circumcised will not be disturbed by the unseen beings.

In the month of Safar, the Bugis-Malay people in Ambawang hold a makan kampong (village meal ritual). This event is associated with the belief that in 
the month of Safar there are a lot of major disasters. Therefore, according to some people, if eating the village is not implemented in the coming season, there will be a disaster. For example, some people may drown in the river). The food that must be prepared is roasted chicken, yellow sticky rice and boiled eggs. In this procession, villagers are also involved in making and carrying the ketupat tolak bala (sticky rice wrapped in coconut leaves for chasing the evil away). Ketupat is brought by each family on Wednesday morning, collected by a kind of committee ${ }^{5}$ and after that it is served at the venue. People who come to the even sit facing each other, and in the middle they serve a dish. In addition to carrying ketupat with them, villagers also prepare seven-color threads, which are used as bracelets. The 7-color threads are spun and then cut into short pieces of about $20 \mathrm{~cm}$, enough for a bracelet. Bracelets from these threads are distributed to those who come at the time of the prayer reading. Those who wear the bracelet are believed to be not disturbed by evil spirits, especially those traveling on the Landak River. The prayer is read on a bridge in the downstream river. The event is led by a village shaman who is also a Muslim religious leader here.

The Qur'an verses, Surat Alfatihah, certain verses and shalawat are read by the village shaman to "heal" people. This is part of the village medical treatment. If there are children who are sick, they will be brought to the shaman. The shaman here is called Abah who gives out medicine in the form of water which has been read out with prayers. The same thing is found in the Madurese community. Recitation is the entrance for seven monthly activities. For the first child the tradition must have been carried out by most Madurese people. The procession starts by inviting the men or neighbors to the recitation activities and reading the prayer at home. After the recitation, a procession is performed to bathe both the prospective father and mother led by the shaman or those who understand the ritual.

Another hijri month celebrated by Madurese is the month of Muharram. They hold recitals or shalawat in mosques and invite religious teachers to lecture. They also make Muharam porridge which is eaten at home and partly delivered to neighbors. This Muharam porridge consists of white rice mixed with sweet potatoes, such as cassava and sweet potatoes and then mixed with sweet corn. Muharram is also celebrated by the Javanese. On the first day of Suro, the Javanese people here gather in one place, usually in the field or village hall. They come in the afternoon after Ashr prayer time, carrying rice with them complete with side dishes wrapped in banana leaves. All rice is collected or

${ }^{5}$ Actually it is not necessarily a formal committee, because the activity preparation meeting and the formation of the formal structure of the organizers has never been done. So, those who play such roles as food collectors are actually due to their own initiative. 
lined up and then recited by local religious leaders. This ritual is held at night after Maghrib prayer. They also perform fasting for one day and do not sleep for a day and a night. During that no-sleep period, they pray and read the Qur'an.

\section{ISLAM IN THE CULTURE OF THE MULTICULTURAL PEOPLE IN AMBAWANG}

As mentioned before, several ethnic groups in Sungai Ambawang are Muslim. The religion is an important part of the culture they practice. Religion is inseparable part of the culture of some communities here. This assumption is based on the fact that in society, the timing of various cultural activities is based on the Islamic calendar. Beruah in the Javanese community in Ambawang is carried out after Maghrib prayer. The selekoran event for the Madurese community is carried out after Tarawih prayer. Meanwhile, other hijri months that are celebrated in the cultural activities of the people in Ambawang include the months of Muharram, Sya'ban, Maulid, etc. For example, there is the celebration of the forst day of Suro which is held in the month of Muharram. Celebration of Sya'benan in the month of Sya'ban. The activities of Moliten or Maulidan among Madurese are carried out in the month of Maulid. Maulid is the birth month of the Prophet Muhammad, namely in the month of Rabiul Awal, the Madurese people welcom this momentum with sermon, prayer and meals together.

The activities of the selekoran among the Madurese are based on the Islamic calendar, namely Ramadan. This activity is held on the 21st of Ramadan. It also applies to the skemian activity, which falls on the 25th night of the Ramadan. On that night, people eat black and white sticky rice. The determination of the beruah in the Javanese society is based on Islamic calendar, too, namely in the month of Ramadan. Beruah is held at the beginning of Ramadan to welcome the arrival of fasting. Therefore, among Javanese, the beruah event is also called selamatan puasa (ritual for welcoming the fasting month) or selamatan ruahan. The preparation of Muharam porridge is also based on Islamic calendar, namely the month of Muharram. This porridge is made in Muharram, but the date or day is flexible. The months of Rajab and Sya'ban also serve as a marker for the time of the implementation of earth charity among the Javanese people.

In the life cycle of multicultural communities in Sungai Ambawang, it is clear that Islam is an important part of their culture. For example, the Qur'an is read on the 7th anniversary of pregnancy among Madurese. At that moment, they read Surah Yusuf and Maryam. Certain verses in the Qur'an are also 
used to treat sick people by the Madurese and Javanese here. These verses are recited onto a glass of water which is then drunk or applied to the body part of the sick person. Prayers in Arabic are materials that are also used in the culture of the people in Sungai Ambawang. For example, the recitation of a prayer after a woman gives birth in the baso lantai event. The prayer is also recited during the village meal ritual which is held on a bridge in the lower part of the river at Parit Aim I, Sungai Ambawang. Likewise, at the time of treatment, the village shaman recites a prayer onto the water that is drunk or rubbed on a particular part of the patient. In addition, prayers are also recited at the Selekoran event. Prayers are read when mosque worshipers had gathered around the food delivered by women. Prayers are also recited at the time of conducting maulidan activities, at the Selekoran, and at the sedekah bumi event. Shalawatan, an expression of praise for Prophet Muhammad is used in several cultural activities in communities in Sungai Ambawang.

Shalawat is recited in the seventh month bathing event for pregnant women in the Madurese community. Before bathing the prospective father and mother, shalawat is always recited first. Shalawat is also used to conclude spells in healing by village shamans among the Madurese. In fact, according to one informant in almost all activities involving many people, a prayer is always conluded with shalawat. This shalawat serves as the closing part of the whole series of activities, as well as being a marker for the host and invitation to part. If shalawat is already recited, it means that the guest may leave the invitation assembly. Shalawat is also recited during the procession of a groom headed for the bride's wedding home in the Javanese customs. This shalawat is recited with tambourine playing so it is often part of entertainment in this activity.

Apart from Prophet Muhammad, Prophet Khaidir, a prophet mentioned in the Qur'an, is also involved in traditional events in Ambawang. In the event of buang-buang, for example, when dissolving a number of traditional properties into the water, it is recited as follows:"Bismillahir rahmanir Rahim. Assalamualaikum Nabi Khaidir." Serakal or sometimes called srakal and srokal is the name referred to in one part of the contents of the book Al-Barzanji written by Ja'far bin Hasan al-Barzanji ${ }^{6}$. As seen in the community in Sungai

${ }^{6}$ The book Barzanji which is well-known for the name "Mawlid al-Barzanji", is the most popular and most widespread mawlid book spread throughout the Arab and Islamic countries, both in the East and in the West. Many people memorize it and read it in religious social activities. The development of Barzanji recital in West Kalimantan has been more or less influenced by ulama in the Pontianak Sultanate, Uthman Al-Puntiani bin Syihab Al-Din. He was known as a student of Muhammad Shalih, brother of 'Abdallah Al-Zawawi, the Mufti of Pontianak in 1891, and 'Uthman also translated Al-Barzanji's mawlid. (Van Bruinessen, 1998). The contents of the book Al-Barzanji is summary of sirah nabawiyyah which includes the story of birth, apostolate, migration, morals, war and the death of the Prophet.

Because it originates from the Islamic world, containing praise for the Messenger of 
Ambawang, Islamic poetry is chosen as part of recitation in children's haircut ritual. Serakal is recited after prayer.

Places of worship such as mosques have long been known as symbols of a Malay community (Yusriadi, 2014). In Sungai Ambawang the same conditions are also common. The mosque is also a cultural identity of the people there. In some areas of this place, the mosque serves as the center of activities. For example, activities in the Madurese community are mostly carried out at the mosque. The Muharram celebration is also held at the mosque by inviting preachers. So are the maulid activities, in addition to being held from house to house, they are also held collectively at the mosque. There are sermons and meals during the activity.

Almost all customary events, as reported by the informant, involve religious officials or people who understand about Islam. Muslim leaders have the task of reciting prayers on the baso lantai event. Religious leaders are also involved in reciting prayers during the first day of Suro celebration in the Javanese community. Prayers are recited for food that has been collected. Their involvement in cultural activities has these activities rich with Islamic characteristics. Presumably, this is what causes the people in the Sungai Ambawang region, the Malay tribes, Bugis, Javanese and Madurese, to be synonymous with Islam. If you mention the names of ethnic Malays, Bugis, Javanese and Madurese, then what comes to mind is a Muslim ethnic groups. The involvement of the leader, clothing, place, time, or the use of certain recitation from the Qur'an and prayers in Arabic, is a sign that the Islamic element is an ethnic identity in Sungai Ambawang. It gives the same nuances, namely the reflection of Islam in people's lives, as well as being a distinct identity in identifying the form of "Islam" in the community here, while at the same time showing that local Islam is indeed colorful (Abudin Nata, 2010). Islam that is practiced and demonstrated by the people in Sungai Ambawang becomes flowery, as is the characteristics of Islam in the archipelago in general (Azyumardi Azra, 2015).

What happened in the community shows that there is an effort to maintain or strengthen identity. There are several ways that people usually do to maintain their identity, including: using it often, there is a learning process, and there are activities for the creation of psychological images (Abdur Rahman, 1999). The use of Islamic elements in the culture of the people in Sungai Ambawang shows that identity will continue to be maintained. The indications include routine activities; that is once a year for certain activities. In fact, to keep the

Allah, written in Arabic, this sermon is considered a type of Islamic poetry. By the people in Ambawang and various places in the Indonesian Archipelago, reciting this poem is an important part of the prayer asking for a child's safety ritual. 
routine going, sometimes included with the myth ${ }^{7}$. Because these activities are carried out consistently, Islamic traditions can continue to be maintained. Certain people involved in the activity will remember how the prayer should be recited. They will also pass it down to the next generation. In certain activities, it appears that there are indeed learning activities. The next generation learns from the previous. For example, in reading the Qur'an, almost every place there is a Qur'an study group. It is also the case with Islamic art such as hadrah and serakal. These activities are passed on by conducting joint exercises that seemed semi-formal.

In addition, such preservation also occurs because there are pragmatic reasons for imaging. In terms of actors, as mentioned in Shamsul A. Baharuddin (2001), there is always an element of the interests of the actor to maintain a cultural form. The performance of a form of culture will be a stage to appear in public. This stage will give a good image, because from the social perspective, there are positive implications for the actor. Religious leaders, for example, gain more respect and appreciation than other citizens in the activity. Their sacred role will make them an important person. In addition, this position will have an impact on one's image in everyday life. A ceremony leader, including a shaman and prayer reciter, is an important person in the community. In another sense, they are not ordinary people and therefore they must be treated as important and respected people. Therefore, it is natural that later on from a certain point of view, the community would recognize the necessity to preserve a form of culture. If certain cultures are not preserved, then there will be unwanted impact on their life. Those who are supposed to carry out certain cultural or customary activities but do not do it will encounter misfortune.

\section{CONCLUSION}

The communities in Sungai Ambawang, Kubu Raya, are made up of various ethnic groups. There are ethnic Malay, Bugis, Javanese, Madurese, and Kanayatn or Ahe and Chinese. They can easily be found in the social space of life in Sungai Ambawang. They organize cultural activities for certain moments as part of their life cycle. These ethnic groups practice various forms of culture. The Malay, Bugis, Javanese, Madurese, have many forms of culture that reflect the Islamic elements or language. The Islamic elements, among others, are the time selected to hold events in the hijri calendar, the use of verses or words from the Qur'an, prayers in Arabic, Shalawat and Islamic poetry, activities in mosques, and the involvement of Islamic figures in these activities. The use

${ }^{7}$ The myth, among others, "If people do not carry out these activities, they will have disasters", "If someone does not carry it out, they will be criticized maliciously", etc.. 
of Islamic elements is maintained in the community in Sungai Ambawang, through educational activities and the creation of impressions. The image generated and the implications of some cultural activities strengthen the Islamic identity.

The use of Islamic elements in culture has led to a mix of cultures, which has implications for the face of the local culture of each ethnic group. In the end, as seen today, the face of Islam is flowery and colorful. That is a reflection of local people's acceptance of Islam. That is part of the form of Islam that lives in the middle of the Nusantara society, which is identified as the Nusantara Islam.

\section{BIBLIOGRAPHY}

Alexander, A. K. (2005). Salako or Badamea. Wiesbaden: Harrassowitz.

Alloy, S. at.al. (2008). Mozaik Dayak, Keberagaman Sbsuku dan Bahasa Dsayak di Kalimantan Barat. Pontianak: Institut Dayakologi.

Amin, F. (2013). Kitab Berladang. Pontianak: IAIN Pontianak Press.

Azra, A. (2015). Islam Nusantara. in Resonansi of Republika. 18 Juni 2015.

Baharuddin, S. A. (2001). Identiti dan Pembentukan Identitas. Peper presented at Seminar Dayak Islam di Kalimantan Barat, STAIN Pontianak MABM-KB.

Barth, F. (1988). Kelompok-kelompok Etnik dan Batasannya. Translated by Nining Soesilo. Jakarta: UI-Press.

Darsani, H. (2014). Edi Berjanji Lestarikan Budata Melayu di Kubu Raya. Tribune Pontianak, Sabtu, 13 September 2014.

Enthoven, JK. (1905). Borneo's Wester-afdeeling. Translated by Yeri. Pontianak: Institut Daytakologi.

Geertz, C. (1960). Agama di Jawa: Konflik dan Integrasi. Translated into Indonesian. Yogyakarta: Komunitas Bambu.

Hermansyah. (2009). Ilmu Ghaib di Kalimantan Barat. Jakarta: PT Gramedia. . (2004). Magi Ulu Kapuas: Kajian atas Ilmu masyarakat Melayu Embau. Unpublished Thesis. IAIN Walisongo Semarang.

Isman, Z. (2003). Kajian Perubahan Terhadap Orang Melayu Pesisir dan Pedalaman. Unpublished Thesis. Institut Alam dan Tamadun Melayu (ATMA) Universiti Kebangsaan Malaysia (UKM), Bangi.

Lontaan, J.U. 1975. Sejarah - Hukum Adat dan Adat Istiadat Kalimantan - 
Barat. Pontianak: Pemda Tingkat I KalBar.

Mesthrie, R. \& Tabouret-Keller, A. (2001). Identity and Language. In Mesthrie, R. Concise Encyclopedia of Sociolinguistics. p. 165-168. Amsterdam: Elsevier.

Muttaqien, I. (2014). Nilai Inti (Core Values) Masyarakat Meruhum di Pulau Lemukutan. Jurnal Khatulistiwa. Vol 4. No. 2. Hal: 139-147.

Nata, A. At.al (2010). Islam dan Budaya. Jakarta: Kalam Ilmu.

NU Online. (2018). Tanggapi Mamah Dedeh, PBNU: Masih Banyak Orang Salah Paham Islam Nusantara. www.nu.or.id. Retrieved on Wed, 04 July 2018.

Purba, J. At.al. (2009). Sejarah dan Perkembangan Budaya Melayu di Kalimantan. Jakarta: Ditjen Sejarah dan Kebudayaan, Kemendikbud RI.

Prasojo, Z.H. (2011). Indigenous community identity within Muslim societies in Indonesia: a study of Katab Kebahan Dayak in West Borneo. in $O x$ ford Journal of Islamic Studies. Vol. 22. No. 1., P. 50-65.

Rahman, A. (1999). Identiti dan Pembentukan Identiti. Akademika. 55: i-xii.

Robertson, R. at.al. (1997). Agama dalam Analisis dan Interpretasi Sosiologi. Kuala Lumpur: Dewan Bahasa dan Pustaka.

Robertson, R. at.al (1997). Agama dalam Analisis dan Interpretasi Sosiologi. Translated into Indonesian. Kuala Lumpur: Dewan Bahasa dan Pustaka.

Riwut, T. (1979). Kalimantan Membangun. Palangkaraya: Pemda.

Van Bruinessen, M. (1998). Tarekat Naqsyabandiyah di Indonesia; Survei Historis, Geografis dan Sosiologis. Bandung: Penerbit Mizan.

Veth, P.J. (2012). Borneo Bagian Barat, Geografis, Statistis, Historis, Jilid 2. Terjemahan P. Yeri, OFM.Cap. Pontianak: Institut Dayakologi.

Yusriadi, at.al (2009). Menunggu di Tanah Harapan, Catatan dari Kampung Eks Pengungsi Sambas. Pontianak: STAIN Pontianak Press - Malay Corner.

Yusriadi, (2014). Sejarah dan Perkembangan Orang Melayu di Riam Panjang, Kalimantan Barat. Jurnal Khatulistiwa, Vo. 4 No 2. P. 148-168.

-------, (2014a). Identitas Orang Melayu di Hulu Sungai Sambas. Unpublished research report.

-------, (2014b). Identitas Budaya Orang Bakumpai. Pontianak: STAIN Pontianak - BPNB Pontianak. 
-------, (2005). Bahasa dan Identitas di Riam Panjang, Kalimantan Barat, Indonesia. Ph.D thesis. Institut Alam dan Tamadun Melayu (ATMA) Universiti Kebangsaan Malaysia (UKM), Bangi.

Yusriadi \& Hermansyah. (2003). Orang Embau. Potret Masyarakat Pedalaman Kalimantan. Pontianak: STAIN Pontianak Press. 
